International Journal of Linguistics, Literature and Translation (IJLLT)

ISSN: 2617-0299 (Online); ISSN: 2708-0099 (Print)

DOI: $10.32996 / \mathrm{jjllt}$

Journal Homepage: https://al-kindipublisher.com/index.php/ijllt

IJLLT

\title{
(Re)reading Acculturation Process in Multicultural Space of Zadie Smith's NW
}

Maryam Shokouhi ${ }^{1 *}$, Kaihan Bahmani ${ }^{2}$ \& Leila Baradaran Jamili ${ }^{3}$

${ }^{1}$ PhD Candidate in English Language and Literature, Islamic Azad University- North Tehran Branch, Department of English

Language and Literature, Tehran, Iran

${ }^{2}$ Assistant Professor, Department of English Language and Literature, Danesh Alborz University, Qazvin, Iran

${ }^{3}$ Assistant Professor, Department of English Language and Literature, Borujerd Branch, Islamic Azad University, Borujerd, Iran

Corresponding Author: Maryam Shokouhi, E-mail: Maryam.shokouhii@gmail.com

\section{ARTICLE INFORMATION}

Received: October 02, 2020

Accepted: November 15, 2020

Volume: 3

Issue: 11

DOI: $10.32996 / \mathrm{ijl} \mid \mathrm{t} .2020 .3 .11 .2$

\section{KEYWORDS}

Acculturation, conviviality, ethicosocio-cultural approach, ethnic absolutism, multiculturalism, the Other

\section{ABSTRACT}

The present study seeks to delineate the impact of the Other on the acculturative options of the diasporic minorities in the multicultural space of Zadie Smith's NW (2012). The extent to which the selected characters can be successful in acculturation process to experience conviviality and escape from ethnic absolutism will be discussed by taking an ethico-socio-cultural approach. The interdisciplinary approach includes ethical philosophy of Emmanuel Levinas, Paul Gilroy's sociocultural critique of contemporary multiculturalism in Britain, and John Widdup Berry's acculturation theories. This article attempts to demonstrate not recognizing the Other's difference can be the main cause of the failure of multiculturalism. Time in its philosophical and temporal sense is associated with race to evoke the way past can lead to the present inter-subjectivity breakdown; moreover, the role of ethical responsibility in the subjects' acculturation process will be addressed.

\section{Introduction}

Zadie Smith (1975) is a contemporary British novelist, essayist, and short story writer associated intimately with London. She articulates a narrative of marginality reflecting her personal experiences in the area she grew up. Her works represent consequences of the growing increase in migration of people with different racial, ethnic and cultural backgrounds in multicultural British society. The increase in the number of refugees and the position of minorities and their influential role on the governing politics of inter-subjectivity relations can be traced in most of her works. It seems that in her works, if a healthy process of acculturation is not pursued, it can lead to disorder and controversy.

Smith's NW (2012) is more character based rather than plot based (more psychological than incidental). Each character is dangling between "rout and root" and therein lies the significance of time in relation to the place (Gilroy, et al., 2019, p.174). The novel demonstrates the life of four main characters: Leah Hanwell, Natalie Blake, Felix Cooper and Nathan Bogle, along with some minor characters living in the North West (NW) London. The narrative techniques used by the author and multiple problems existing in each subject's life reflect the polyphonic nature of contemporary urban life. $N W$ is divided into different sections to make the reader conscious of being located at the heart of a fiction and an active reader able to investigate the subjects' problems in a multicultural society.

Application of Emmanuel Levinas's philosophy on Paul Gilroy's views paves the way to depict the inter-subjectivity breakdown, and different acculturative options in the multicultural space. In Gilroy's view, "it now appears as though any desire to combine cultural diversity with a hospitable civic order...must be subjected to ridicule and abuse; [however]...the briefest look around confirms that multicultural society has not actually expired" (2004, p. 1). Consequently, the idea of expiration of multicultural society has only political reasons in service of abolishment of plurality and solidarity.

Gilroy opposes "the dry dogma of a ready-mixed multiculturalism, [and] offers an unorthodox defense of this twentiethcentury utopia of tolerance, peace, and mutual regard" $(2004$, p. 2). Subjects can survive only if they can live with difference

K
C
Published by Al-KindiCenter for Research and Development. Copyright (c) the author(s). This is an open access article under CC BY license (https://creativecommons.org/licenses/by/4.0/) 
in an increasingly divided society. Once a minority group settles down in a multicultural society with different ethnic or racial groups, they may witness different acculturation strategies. The more they are successful in integrating with 'the Other', the less they will enter the realm of stress and isolation in their social and private relations. In Berry's view, there is a one-to-one relation between how well the subjects adapt at individual and group levels and the level of acculturative stress they experience.

The researchers will elaborate on the interdisciplinary approach utilized in this study to make the grounds for examining the extent of the characters' success in the acculturation process. Through an ethico-socio-cultural approach, this study attempts to extend the current theories of multiculturalism. Therefore, in the theoretical framework, Levinas's philosophy of ethics and its application on Gilroy's concepts of ethnic absolutism and conviviality will be studied. Then, the impact of 'the Other' on the acculturation process of the subjects in multicultural context will be dealt with. The present study addresses the role of 'the Other' and time in the acculturation process of the subjects in multicultural NW. This article aims to answer two questions: first, how can Levinas's time and Otherness be utilized to approach obsessions of racial and ethnic minority subjects and/or those surrounding them? Second, what is the role of responsibility of 'the Other' on the acculturation process of the subjects in multicultural world? In answering the first question ethical philosophy of Levinas will be discussed. And, in answering the second question, the impact of the lack of responsibility of 'the Other' and its consequences on the acculturation options will be enumerated.

\section{An Ethico-socio-cultural Approach to Multiculturalism}

In this study, Paul Gilroy's socio-cultural reading of race and politics of racial and ethnic minority settlement in multicultural London have been considered under the light of ethical philosophy of Emmanuel Levinas. It is attempted to show that Gilroy and Levinas's works are dedicated to end racism, each in their own way. Gilroy endeavours to prove future generations are not sprung from pure racial identity. His rejection of ethnic absolutism to the researchers' view has an ethical root that will be associated with the thoughts of Levinas. Ethnic absolutism in this way is the cause of the worst atrocities of modern era and culture. To stand against it is possible only if "members of the dominant social group in a racialized society need not imagine themselves to be superior: they need only assert unbridgeable difference to awaken fascist solidarity" (Gilroy, 2000, p. 90). Therefore, fascism has its roots in the attempt to view the society in a holistic way without any difference.

Today's problem is the inability of the subjects to locate "the Other's difference in the commonsense lexicon of alterity" (Gilroy, 2004, p. 137). Gilroy's rejection of ethnic absolutism refers to the idea that humans belong to different ethnic compartments, with biological race regularly taken to be the basis of human differentiation. He writes extensively about ethnic absolutism, because he is consistently opposed to it. On the other hand, Levinas finds much of the atrocities of modern world in 'totality'. He asserts, "men, their misery and despair, their wars and sacrifices, the horrible and the sublime are all resolved and summed up in an impassive order of the absolute and the totality" (Levinas, 1998, p. 54). Consequently, the horrors of race-thinking and fascism in Gilroy's thoughts are rooted in Levinas's concept of 'totality.' As Levinas stands against 'totality' to emphasize the individuality of the subjects, the heterogeneous origin of Britain could be read as an attempt to celebrate ethnic difference.

In Gilroy's view, conviviality is "the processes of cohabitation and interaction that have made multiculture an ordinary feature of social life in Britain's urban areas and in postcolonial cities elsewhere" (2004, p. xi). Hence, conviviality is a process in which people with different backgrounds accept their difference as a facet of daily life. One of the characteristics of conviviality that distinguishes it from multiculturalism is the dynamism and openness to 'the Other'. Conviviality is the result of living with 'the Other' while accepting its difference. The "radical openness" in the concept of conviviality stands in opposition to the "closed, fixed, and reified identity" making the concept of identity dynamic (Gilroy, 2004, p. xi). The researchers believe that "the always-unpredictable mechanisms of identification" is a proof on the ethnic minority subjects' freedom to choose among the acculturation options (Gilroy, 2004, p. xi).

The inter-subjectivity relationship has been demolished in NW due to the subjects' failure in spontaneous openness to the new while being able to recognize the old. Corporate multiculturalism stresses equality; at the same time, it acknowledges that every member of society should have their "separate, unmixed culture acknowledged" (Gilroy qtd. in Williams 670-1). In culturally plural societies, subjects face different options in their relation to other groups and people in the same group they are dwelling with. There is a relation between 'the Other' and the successful acculturation process of the subjects. In "Acculturation and Adaptation in a New Society" Berry explains assimilation, integration, separation and marginalization as follows: 
Assimilation option is defined, namely, relinquishing one's cultural identity and moving into the larger society... The Integration option implies some maintenance of the cultural integrity of the group (that is, some reaction or resistance to change) as well as the movement to become an integral part of a larger societal framework (that is, some adjustment). When this strategy is widely adopted, there are a number of distinguishable ethnic groups, all cooperating within a larger social system...[Segregation or Separation occurs] [w] hen there are no substantial relations with the larger society, accompanied by a maintenance of ethnic identity and traditions, another option is defined. [Finally] Marginalization takes place [when] groups lose cultural and psychological contact with both their traditional culture and the larger society (either by exclusion or withdrawal). (p. 72)

In assimilation, the subject is willing to welcome the new culture and be part of a "larger society" (Berry, 1992, p. 72). In integration process, the subject remains to some extent loyal to the cultural and social traditions and resists complete change leading to creation of ethnic minority groups. Next, segregation or separation is the outcome of extreme resistance to change and adaptation. Ultimately, if the subjects are alienated from their traditional culture and current society, marginalization takes place. As diversity is an inevitable part of multicultural societies, the subjects' success lies in their ability to adapt.

Root is always a place of question for the blacks; the lack of reference to the origin is discussed by Gilroy to highlight the process rather than the origin as the end point. The concept of diaspora in this study is based on Gilroy's view as "a very particular kind of diaspora...that can't be reversed" (Gilroy qtd. in Williams, 2013, p. 115). Therefore, the first initiative to continue with the concepts of acculturation process and difference among minorities is assumed to be accepting the importance of rout and the anti-holistic view of the ethnic and racial minorities. Levinas defines responsibility "as responsibility for the Other, thus as responsibility for what is not my deed, or for what does not even matter to me; or which precisely does matter to me, is met by me as face" $(1982$, p. 95). Hence, this idea gives the space to Gilroy to set up a decisive change of standpoint in the relation between place and identity to define culture.

\section{Politics of Time and Otherness in NW}

Time has a significant claim on the present life of the subjects in NW. Leah and Natalie have been brought up together and share a good understanding of each other's dreams and worries. The colour of their skin makes them different from outside whereas they share many of each other's interests. Leah is a white social worker who is content with her lifestyle and does not show much interest in changing her social class; she shows little interest in the upper-class lifestyle while Natalie is completely the opposite. Though a great share of the novel is dedicated to the two female characters, other characters like Michel, Felix and his father Llyod, and Nathan will be addressed in this article as well.

Leah is a married woman in her thirties who seems interested in having baby but is afraid of getting pregnant, so she takes birth control pills without her husband's consent. Her fear of having baby could be approached by Levinas's thoughts on time and death. In Levinas's view, "the future that death gives, the future of the event, is not yet time. In order for this future, which is nobody's and which a human being cannot assume, to become an element of time, it must also enter into relationship with the present" (Levinas, 1961, p. 79). Leah is believed to be a symbol of death, since she cannot "enter into relationship with the present' (Levinas, 1961, p. 79). She is got stuck in the past and is reluctant to relate to Michel or Natalie.

While technology helps Michel break the racist border, it has a destructive role for Natalie. Leah teases Natalie and calls her "coconut" since in her mind she is black outside but white inside (Smith, 2012, p. 56). Leah cannot get along with Natalie's supernumerary effort to change her social class and live like upper-class whites. It seems that being the only white person justifies Leah's inactive lifestyle. However, regardless of skin colour what makes the distinction between the black and white characters of the story is that for the black ones "[t]his past that is already past is attested to in anxiety" whereas for Leah future signifies 'death' and is the port of much anxiety (Levinas, 2001, p. 59). Leah enjoys spending time with Natalie since she is "the only person [she] can be all of [herself] with. Which comment made Natalie begin to cry, not really at the sentiment but rather out of a fearful knowledge that if reversed the statement would be rendered practically meaningless" (Smith, 2012, p. 167). There is one common shared characteristic relating all the three black characters: though Leah feels close to them and has no mask on her face to conceal her feelings, they are not true to her.

Same rights in married life is one of the main problems of Leah. She cannot reduce herself to the framework of a female character in married life. Though, Michel is breadwinner of the family, Leah cannot move to the next step in their married life by giving birth. The main question to be answered is the motivation of this decision. Levinas believes that "the situation of the face-to-face would be the very accomplishment of time; the encroachment of the present on the future is not the feat of the subject alone, but the intersubjective relationship. The condition of time lies in the relationship between humans, or in 
history" (Levinas, 1961, p. 78). So, Levinas artistically relates the concept of time to 'the Other' that can be meaningful only in "intersubjective relation" (Levinas, 1961, p. 78). In other words, all the obstacles Leah experiences with time is a consequence of not positing time in its place and failing to face the Other in an "intersubjective relation" (Levinas, 1961, $p$. 78).

Leah is against the social definition of a family and tries to rewrite it. Wells states, "Smith's narrational style in the first section of the novel, 'visitation', underscores Leah's separateness not only from Michel but also from others in her life: her mother Pauline, her co-workers, and even Natalie, with whom her bond of intimacy has eroded over the years as they have grown in different direction" (2013, p.104). Unlike Natalie's attempts to welcome the mainstream norms of the white society regarding a wife's role, Leah tries to separate herself from others. Consequently, the gap between her and her family becomes deeper.

In the relationship between Michel and Leah one of the main obstacles in growing the love between them is the concept of 'death' permeating in Leah's thoughts throughout her life. As a student, she studies philosophy for the simple reason that "[p]hilosophy is learning how to die" (Smith, 2012, p. 33). Also, that philosophy bounds one to a deeper understanding of place and time and "[i]t is wishing yourself anywhere else, in a different spot somewhere in the multiverse which is a concept you will never truly understand. In the end, only one idea reliably retained: time as a relative experience, different for the jogger, the lover, the tortured, the leisured" (Smith, 2012, p. 33). The researchers believe that the relation between time and death is significant in studying the role of Michel as 'the Other' in the life of Leah. But in Levinas's words, "vanquishing death is to maintain, with the alterity of the event, a relationship that must be personal" (1961, p. 81). The problem with Leah is that she cannot see that "death is not, then, the ending of a duration made up of days and nights but an ever open possibility" (Levinas, 2001, p. 47). In other words, she does not see any positivity or "open possibility" in death (Levinas, 2001, p. 47).

Leah's obsession with death is implied in recreation of her dead father. Due to her fear of future, in an imaginary speech with her dead father "she starts to make her father say things, directing him, moving his arms and manipulating his expressions, first innocently, and then with deliberation." (NW 47). In her imagination, she tries to force her father to express his love and affection to her; this can be an attempt to convince herself of a positive view of death. The main motivation behind this picture is the fear of death and, consequently, future.

Speaking of the ethics of Emmanuel Levinas, "in ethics, in responsibility for another, it is a question of the nearness of the other who obsesses me without measure, to the point of placing in question my in-itself and my for-itself" (Levinas, 2001, p. 140). In responsibility towards 'the Other', there is a 'relationship that is never finished with the other' (Levinas, God 160). So speaking of Levinas's concept of responsibility, a relation is hidden that is not time-bound. In other words, in reviewing the inter-subjectivity breakdown of the major characters, the problem can be traced in the lack of constant care toward 'the Other'.

No matter how devastated Leah is in her personal life, she plays the role of 'Other' to the people encountering her. The word play on Leah's name is noteworthy as "Leah is an anagram for heal, and reaching out to others-especially those who need help" (Custer 76). Leah's problem can be that there is no one to take the role of a healer for her. Race is a significant notion for the black characters including Michel. He tells Leah, "you know what is the true difference between these people and me? They don't want to move forward, they don't want to have nothing better than this. But I'm always moving forward, thinking of the next thing" (Smith, 2012, p. 30). Michel is so concentrated on his own personal success that does not care about Leah, the white, living with him. Michel's sole goal in life is "climbing the ladder" as if his marital union with Leah has been part of the plan to facilitate the process for him (Smith, 2012, p. 30).

To unravel the secret surrounding the subjects, their past and the extent of its influence on their present life in multicultural space of London should be observed. Beings relation with the past is significant in shaping the present subjects' responsibility in encountering "the faults or the misfortune of others" (Levinas, 1998, p. 54). The freedom that Levinas believes in is not the same for 'the Other' and oneself; therefore, neither side has a demand over the other's decisions. Natalie is a married and highly successful lawyer who could ascend the success ladder and, consequently, be welcomed by the upper class. She has two identities living hand in hand; one is Keisha with Gmail address: KeishaNW@gmail.com that belongs to Caldwell where she used to live as a child. Keisha is a pervert person lacking appropriate sense of responsibility. The second face of her is the successful Natalie whose name has been given to her at her college years and is an exemplar of high-class woman with a family who is very caring and loyal to her husband and two kids. But, upon revelation of her secret, the final station at the life of the only happily married couple of the story takes place. 
The concept of time gets mysterious by the disorienting method Smith uses in depiction of the events. By demystifying the time for Felix and his father Llyod, Nathan and Frank, who are the focal characters in this section, the reader can reveal the secret each one conceals. Due to colonization and migration it seems that time has lost its natural flow for the black characters. Levinas discusses "temporalization" of time as "falling out of phase" according to which time loses its "temporal flow" (Levinas, 1998, p. 9). The researchers argue that as the ethnic and racial minorities have a different experience of time, they experience different acculturation options as well.

Felix is first introduced to readers on TV news when Michel watches a report on Felix's death news in Albert Road. Further details are discussed in a section named 'guest'. Felix's father is a Jamaican migrant and his mom's root goes back to Ghana. Felix and his father came to London to start a new life; however, it turned out a catastrophe due to the lack of responsibility to the migrants by the society. The short life of Felix is a good example of failure of ethics in Smith's multicultural space of London.

Lloyd, Felix's father, lives in past and has imprisoned himself in his apartment. For him time has stopped moving forward and, consequently, by not going outside he tries to remember only the past as if it protects him from the current social injustices at work in the present time. In the past few years, Felix's father had different experiences of 'the Other' and the world outside. After all, he has deepened the gap to feel safe. Past is a threat and bitter memory to Lloyd. Drabinski suggests, "in a global (or globally entangled) context, the enigma of beginning after catastrophe is especially central to the twentieth century and so many of its attendant anxieties" (2011, p. 131). Felix is very well aware of the past of his father and this knowledge is the root of much of his responsibility at the present. Felix's father's obsession with past leaves him void of any sense of responsibility.

The only gift Felix has got for his father in the visit is The Autobiography of Malcolm X. But the book revives the dark memories that his father calls "Hard times! You lot don't even know. People now ..." and remembers every person at the pictures (Smith, 2012, p. 90). However, Lloyd has too many troubles that cannot be a character to play 'the face' for Felix. The researchers believe that Smith intends to juxtapose the first and second generation diasporas to portray the failure of multicultural London.

Nathan has the smallest share of the story and is marginalized both by the author and in the society. But his short presence at the life of Natalie is worth mentioning to reveal different layers of multicultural space of London. When Natalie moves back to Caldwell Housing State, after the fight at home with her husband, the only person that recognizes her is Nathan calling her by her old identity 'Keisha Blake'. Throughout the long dialogue between the two, Nathan takes the position of a saviour, since he knows her very well. He tells her "don't pretend you're a nice girl Keisha. I known you from time. Know your family. Cheryl. Suit yourself" (Smith, 2012, p. 241). Therefore, Nathan is 'the face of Other', one who Natalie can see herself at. He can stop time and thus death of Natalie. No matter how hard Natalie insists on being alone, he feels responsible to her and stays with her rescuing her from committing suicide. Nathan is the impeccable Other for Natalie at this stage making her "[find] self-awareness and self-presence after the creative work of the Other" (Drabinski, 2011, p. 129).

No matter how persistent Natalie and Llyod are to get away from Caldwell as the Old State, in Nathan's words, "there's no way to live in this country when you're grown. Not at all. They don't want you, your own people don't want you, no one wants you. Ain't the same for girls, it's a man ting. That's the truth of it right there" (Smith, 2012, p. 249). In other words, diasporic minorities have different experiences of time and place leading to different acculturative options and identities in the multicultural space of London.

\section{Acculturation Options under the Influence of 'the Other' in NW}

What links worries of the subjects is their place of living and their racialized background; however, they have different reactions to these two factors under the impact of 'the Other', ergo leading to different acculturation processes. According to Berry, "acculturation is a process of cultural and psychological change that results from the continuing contact between people of different cultural backgrounds" (Berry, 2006, p. 27). Consequently, the researchers argue that there is a one-to-one relation between 'the Other' and acculturation process that the subjects go through in time.

Leah seeks for "no substantial relations with the larger society," therefore, it could be claimed that she has chosen 'separation' option (Berry, "Acculturation and Adaptation" 72). In Lynn Wells' words, "Leah occupies the stereotypical 
position of ambitionless under-achievement often assigned by mainstream British culture to immigrant and non-white Londoners" (100). Michel, her husband, as the closest person to her takes advantage of technology and tries hard to improve his business. He is an epitome of one who has chosen 'assimilation option' and succeeded in the acculturation process. However, it seems that there is a racist motivation behind Michel's use of technology, since he calls it as a means of being "anyone" (Smith, 2012, p. 30). It gives him the chance to enter a convivial life and get rid of the melancholia he finds in the real black neighbourhood outside. Whereas Leah's life is associated with death and melancholia, Michel is the happy person in their relationship. Therefore, it could be derived that the more subjects move from marginalization to assimilation, the better they distance from melancholic behaviours in multicultural space of London.

While technology helps Michel break the racist border, it has a destructive role for Natalie. When Natalie's secret online relationships are revealed, her husband Frank cannot accept her anymore and asks her out. The identity disorder that Natalie/Keisha suffers from leads to two distinct sets of acculturation options. In other words, Natalie oscillates between two options, because she has a double life. As Natalie, she is a good example of the 'assimilation' option "relinquishing [her] cultural identity and moving into the larger society" (Berry, 1992, p. 72). However, as Keisha, she fits the 'separation' option. The novel ends with Natalie's attempt to solve Felix's mystery of death by calling the police. The significance of the ending is that though Natalie calls the police, it is Keisha who speaks. To this end, once more, the identity disorder of diasporic minorities comes to the surface.

Felix has a short appearance in the novel yet due to his tragic life and death, he can be considered as one of the most memorable characters. His ex-girlfriend, Annie, and his father, Lloyd, fail to fulfil the role of 'the Other' casting him alone in multicultural world outside where he chooses 'separation' option; though some evidence of proceeding to 'integration' option is traceable after meeting his new girlfriend, Grace, yet his death never gives the reader any firm ground about this succession. Lloyd fails to play 'the Other' for Felix, but the readers feel pity for him due to his pathetic situation as a black migrant. It is assumed that Lloyd's entrapment in past is due to his alienation, loss of identity, and what has been termed "acculturative stress" that makes him embody 'marginalization' option (Berry, 1992, p. 73).

Hence Grace is the only person who plays 'the face' for Felix. Grace is a symbol of "the face of a neighbor signify[in] an unexceptionable responsibility, preceding every free consent, every pact, every contract" (Levinas, 1998, p. 88). Grace helps Felix move from the 'marginalization' option to 'assimilation'. She tries to give his life a path, for example she encourages her by stating "Never. Ignorant. Getting. Goals. Accomplished" (Smith, 2012, p. 85). But her presence is such a short one that cannot stop Felix's bitter end.

Nathan is another minor character whose role as 'the Other' helps Natalie survive suicide. Nathan tries to remind her where and who she is. So, the images Nathan portraits make her finally get back home. No matter how successful Natalie or other racial and ethnic minority subjects are in the novel, they always suffer from a sense of lack. The researchers consider Felix and Nathan as two minor characters whose lives depict hidden layers of multicultural space of London represented by Smith. According to Gilroy, "since [England's victory over Hitlerism] the life of the nation has been dominated by an inability even to face, never mind actually mourn, the profound change in circumstances and moods that followed the end of the Empire and consequent loss of imperial prestige" (Gilroy, 2004, p. 97). Studying the role of 'the Other' in alleviating the sense of lack ends up to different attitudes of the subjects in acculturation options.

\section{Conclusion}

This study aimed to rewrite acculturation in multicultural context in the light of the ethico-socio-cultural approach by tracing the politics of Otherness on diasporic identity in Zadie Smith's multicultural space of NW. The application of Levinas's ethical philosophy on Paul Gilroy's critical thoughts on race and race-thinking aimed to locate the politics of abolishment of race and race-thinking in service of homogeneous society in multicultural context. Through the utilization of socio-cultural ideas of Paul Gilroy and ethical philosophy of Emmanuel Levinas, the study concludes that 'the Other' has a claim on the acculturation process of the diasporic minorities in multicultural space of London represented in NW. The dynamic identity of the subjects in relation to 'the Other' is argued to be against ethnic-absolutism that leads to different acculturation options. The selected characters in Smith's NW have a fluid identity, and, through their interactions, they experience various senses of belonging or non-belonging. If the role of 'the Other' is fulfilled, diasporic minorities can move from marginalization to assimilation, and, consequently, experience a convivial life. Hence, this study reflects on celebration of difference as an opposition to the totalistic view of subjects in a homogeneous multicultural society. Almost all characters have experienced post-colonial melancholia; the article showed that a melancholic multicultural space demands conviviality and hospitality achievable via ethical responsibility of 'the Other'. 
NW can be explored from New Historical point of view to delineate the characters' motivations behind their actions from a historical perspective. This approach can provide a novel picture regarding the dynamics of race and identity. Moreover, as the novel is multi-layered, the writer's narratological techniques can also be taken into consideration for future studies. Moreover, the search of subjects in multicultural world can be read under Clifford Geertz insight on the scope of culture, to investigate the possibility of intelligible discourse among members of diasporic groups.

\section{References}

[1] Berry, J. W. (1992). Acculturation and adaptation in a new society. Psychology Department of Queen's University, 69-85.

[2] Berry, J. W. (2006). Contexts of acculturation. The Cambridge Handbook of Acculturation Psychology, Sam D. L. \& Berry J. W. (Eds.), 27-42.

[3] Ciyiltepe, T. (2017). Neoliberal space, place and subjectivity in Zadie Smith's NW- [M.A. Thesis-] -Mac Master University.

[4] Custer, H. C. (2014). Zadie Smith's NW: A compass in sad multicultural land. M.A. Thesis, Appalachian State University.

[5] Drabinski, J. E. (2011). Levinas and the postcolonial: Race, nation, other. Edinburgh: Edinburgh University Press.

[6] Gilroy, P. Nationalism, history and ethnic absolutism. (1990). Oxford Journals, 30, 114-120.

[7] Gilroy, P. (2000) Black Fascism. Indiana University Press, 81(82), 70-91.

[8] Gilroy, P. (2001). Against race: Imagining political culture beyond the colour line. Belknap Press.

[9] Gilroy, P. (2004). After empire: Melancholia or convivial culture? Oxfordshire: Routledge.

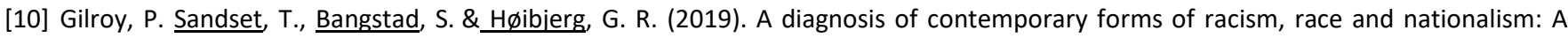
conversation with professor Paul Gilroy." Routledge. 33(2), 173-197.

[11] Levinas, E. (1961). Totality and infinity. (Lingis A.). Pittsburgh: Martinus Nijhoff Publishers.

[12] Levinas, E. (1982). Ethics and infinity: conversations with Philippe Nemo. (Cohen, R. A., Trans.). Pittsburgh: Duquesne University Press.

[13] Levinas, E. (1987). Time and the other. (Cohard, R. A. Trans.). Pittsburgh: Duquesne University Press.

[14] Levinas, E. (1998). Entre Nous: On Thinking-of-the-Other. Translated by Michel B. Smith and Barbara Harshav, Colombia University Press.

[15] Levinas, E. (1998). Otherwise than being, or beyond essence. (Lingis, A. Trans.). Pennsylvania: Duquenesne University Press.

[16] Levinas, E. (2001). God, death and time. (Bergo, B. Trans.). California: Stanford University Press.

[17] Paulova, M. (2007). Zadie Smith: A new talent of British literature. Diploma Thesis, Brno.

[18] Schroeder, B. (2005). Breaking the closed circle: Levinas and Platonic Paideia. Emmanuel Levinas: critical assessments of leading philosophers, (Katz, C. and Trout. L. Eds.). Routledge, 285-295.

[19] Smith, Z. (2012). NW. New York: The Penguin Press.

[20] Tew, P. (Ed.). (2013). Reading Zadie Smith: The first decade and beyond. London: Bloomsbury.

[21] Tew, P. (Ed.). (2010). Zadie Smith. Hampshire: Palgrave Macmillan.

[22] Wells, L. (2013). The right to a secret: Zadie Smith's NW. Reading Zadie Smith: The First Decade and Beyond, Tew P. (Ed), London: Bloomsbury. 97-110.

[23] Williams, P. (2013). Paul Gilroy. Oxfordshire: Routledge 